\title{
Discussion on the Effective Application of Applied Linguistics in English Teaching
}

\author{
Wu Qinning \\ NanChang Institute of Science \& Technology
}

\begin{abstract}
Linguistics has a historic and deep influence on the development of human's civilization history since it has recorded the revolution process of human history to some extent. Born in the 17th century in Europe, English linguistics has formed a complete content system through development process in the early, middle and later-period. This paper analyzes the development history of English linguistics with deep study on its effects during subject study. Meanwhile, the paper also proposes new ideas for the development of English linguistics in modern society so that it can better adapt to current development to truly realize the modern development of English linguistics. In the paper, first a brief analysis is made on applied linguistics, and then the effect of applied linguistics on English teaching is explored. At last, the application strategies of applied linguistics in English teaching is discussed. I hope it will provide some help for the study on applied linguistics and the promotion of English teaching.
\end{abstract}

Keywords-applied linguistics; English linguistics; application

\section{INTRODUCTION}

Linguistics is a discipline with a long history. During its long-term development, linguistics has been developed into a big discipline covering all languages. Common languages in all countries have formed relatively systematic and complete content systems during their development, which have been gradually integrated into linguistics, which can enrich and perfect the development mode and framework of linguistics. As we know, any language has its own development rules and process since its emergence, and people have always tried to discover some regular things through constant exploration and study. As a component of linguistics, English linguistics has quite a long history, and its emergence and development also follow the same development way like linguistics of other languages.

This paper analyzes the development history of English linguistics with deep study on its effects during subject study. Meanwhile, the paper also proposes new ideas for the development of English linguistics in modern society so that it can better adapt to current development to truly realize the modern development of English linguistics.

\section{DEVELOPMENT OF MODERN ENGLISH LINGUISTICS}

Since the 20th century, especially the two world wars before the middle 20 century, the world pattern and powers have been thoroughly changed. As for linguistics, English has possessed unlimited development space and influence together with its previous advantages, which has successfully replaced French as the most widely used international official language. In order to adapt to current international situation, countries all over the world have included English in to school education as a compulsory course, which has opened a cultural atmosphere of learning English around the whole society. The language academic world has conducted comprehensive study and exploration on linguistics with the discovery of many new ideas from the perspectives of class teaching methods, English socialization, cultivation of language ability, relationship between language revolution and social development, interactive function between language revolution and social psychology as well as laws of language development. English linguistics has been developed from literary drama language of Shakespeare style to a mature type after centuries of development with its own independent school. It has been developed into a new discipline with complete theoretical system and research methods. 


\section{APPLIED LINGUISTICS}

Applied linguistics is an important part of modern education, and its close relationship with linguistics makes it significant to integrate with English teaching. Thus, experts of education have carried out studies on the application of applied linguistics in English teaching. At present, some achievements have been achieved in this field; however, since the contents of applied linguistics are broad, there are still a long way to be walked so as to make deep studies on the application of applied linguistics in English education as well as other disciplines.

As for the essential meaning of applied linguistics, it can be divided into broad meaning and narrow meaning. The broad sense of applied linguistics is to apply linguistics to other scientific fields, while the narrow sense means the language teaching specifically, especially the teaching of second language. English, as the second language of our country, its position in language education system has determined its internal relationship with applied linguistics, which is also the main force impelling Chinese educators to conduct studies on applied linguistics and English teaching. Although the narrow sense of applied linguistics is concluded as the teaching of second language, it still has some differences between applied linguistics and traditional language teaching. As the experimental field of second language education, applied linguistics is a practice mode of second language education, but not practice education of all second languages is expression of applied linguistics. Therefore, the differences between applied linguistics and second language education should be scientifically distinguished.

\section{THE DIVERSIFIED METHODS OF STUDYING APPLIED LINGUISTICS}

The study of applied linguistics has involved more and more disciplines from narrow sense to broad sense, during which many practical problems are unprecedented new subjects and boundary sciences, some are experience and methods summarized by others, and some are theories and assumptions proposed before without being verification. Investigators of applied linguistics have adopted various research methods according to actual situation to reach different expectation goals, which has further promoted the development of applied linguistics.

It is commonly considered that the study of applied linguistics can be divided into qualitative research and quantitative research. As for qualitative study, researchers can explore the rules, properties and characteristics of language phenomena by written materials or logic deduction to establish theories and models. As for quantitative research, it has been widely applied to the construction of related theories and assumptions for the integration, classification, analysis and comparison of literature documents. The quantitative research pays special attention to the objectiveness of research, which prefers to explain issues with facts and numbers. According to Grotjahn, it is too casual to classify problems into two kinds. $\mathrm{He}$ thinks attention should also be extended to the methods of collecting materials (whether is experimental or non-experimental), types of materials (whether is qualitative or quantitative) as well as analysis on materials (whether is statistical or explanatory).

\section{CONCLUSION}

In practical teaching process, if we need to make breakthrough in this field, we should be first clear about the objective situation, and then we should complete the revolution on English education gradually to seek better effect through gradual and realistic attitude. English, as a language subject, its language characteristic has determined its development way. School education can only teach students some basic knowledge, while the true promotion relies on students' own practice in daily life and daily work. However, as a main platform of cultivating talents, schools should try their best to fulfill their responsibilities and duties by creating a sound learning environment for students to ensure a solid English basis for students' future development.

Applied linguistics has played a significant role in developing English education, which provides supports for English education by analyzing the essence of English language to optimize the English teaching system. Thus English education can serve students in a more correct and more interesting way to improve English teaching effect so as to improve English 
teaching quality. With the analysis on applied linguistics, we hope it can better realize its guiding and promoting functions during English teaching; and meanwhile the educators can deep realize the importance of applying applied linguistics to English teaching, which can provide the most basic and powerful support for the modernization revolution of English teaching.

\section{REFERENCES}

[1] Huang L S. Success in English teaching[J]. Canadian Journal of Applied Linguistics, 2010.

[2] Davies P, Pearse E. Success in English Teaching[M]// Oxford University Press ELT, 2006.

[3] Davies, Paul, and E. Pearse. Success in English Teaching. Oxford University Press ELT, 2006.
[4] Martin. "English teaching and learning in China." Language Teaching 29.29(1996):61-80.

[5] Martin. English teaching and learning in China[J]. Language Teaching, 1996, 29(29):61-80.

[6] Martin. "English teaching and learning in China." Language Teaching 29.29(1996):61-80.

[7] Martin. English teaching and learning in China[J]. Language Teaching, 1996, 29(29):61-80.

[8] Davies, P., \& Pearse, E. (2006). Success in English Teaching. Oxford University Press ELT.

[9] Hill, D. A. (2002). Success in english teaching (book). Elt Journal An International Journal for Teachers of English to Speakers of Other Languages, 56, págs. 424-425.

[10] Huang, Li Shih. "Success in English teaching." Canadian Journal of Applied Linguistics (2010).

[11] Warschauer M, Shetzer H, Meloni C. Internet for English Teaching[J]. Distance Education, 2000, (1).

[12] Hill D A. Success in English Teaching (Book)[J]. Elt Journal An International Journal for Teachers of English to Speakers of Other Languages, 2002, 56:págs. 424-425. 